\title{
THE EFFECTIVENESS OF LEARNING PROGRAMS THROUGH BOY-BOYAN GAME TO DEVELOPE INTERPERSONAL AND INTRAPERSONAL INTELLIGENCE OF KINDERGARTEN STUDENTS
}

\author{
Komala \\ IKIP Siliwangi, Jl. Terusan Jenderal Sudirman, Cimahi, West Java, Indonesia \\ komala.pendas@yahoo.com
}

Received: Desember 15, 2017; Accepted: January 5, 2018

\begin{abstract}
The objectives of this research is to know the effectiveness of learning program through Boy-boyan Game (traditional game from West Java Indonesia) to develope interpersonal and intrapersonal intelegency of PHBS Kindergarten and NEO Mahardika Kindergarten students (TK). This research is motivated by the discovery of the potential development of interpersonal and intrapersonal intelligence of Kindergarten students which is not well developed and it's need to be developed optimally by implementing learning programs Boyboyan game. To formulate the framework program and finding data as material preparation program, so in this study used quantitative approach with quasi experimental methods used against children in group B PHBS and NEO Mahardika that is consisting 20 students as control group 20 students as experiment group. The procedure consists of pre-field research, the implementation of the study, data analysis and reporting the result .Based on the research the researcher found the following result: First, the development of interpersonal and intrapersonal intelligence of kindergarten appeared to vary for each children. Second, the learning program found that the learning program through the traditional game formulations include: rational, goals, objectives and scopes. Third, learning programs through traditional games have a positive effectiveness to improve interpersonal and intrapersonal development of early childhood, from the average obtained that the average experimental group is greater than the control group. It means that interpersonal and intrapersonal intelligence grouped experiment better than the control group or in other words the treatment in the experimental group in the form of learning through traditional games effective in improving interpersonal and intrapersonal intelligence of children. Based on the findings of the above the recommendation of this research is aimed to teachers of kindergarten should enhance the program in accordance with the curriculum related to the themes of learning certain to develop learning activities both theoretical study and practical for children, so that children are able to develop intelligence prominent/dominant in him. For further research should apply the kind of game where the more dominant towards the development of a child's intelligence so that it will appear to optimally increase interpersonal or intrapersonal intelligence of children.
\end{abstract}

Key Words: Boy-Boyan Game, Interpersonal And Intrapersonal Intelligence, and Kindergarten Students

How to Cite: Komala. (2018). The Effectiveness Of Learning Programs Through Boy-Boyan Game to Develope Interpersonal and Intrapersonal Intelligence of Kindergarten Students. JEE, $1(1), 51-58$. 
52 Komala. (2018). The Effectiveness Of Learning Programs Through Boy-Boyan Game to Develope Interpersonal and Intrapersonal Intelligence of Kindergarten Students. JEE, 1 (1), 51 - 58.

\section{INTRODUCTION}

Birth priod untill primary education is the golden age once a critical pase in the stages of human life, which will determine the development of the next child. This period is a period that is very appropriate for laying the foundations of the development of physical ability, language, socialemotional, self-concept, art, moral and religious values. Kindergarten development so that efforts should be initiated so that the growth and development of children achieved optimally. Every children has all kinds of intelligences, but there are only a few dominant or stand inside. Humman is as social beings, they need others to meet their social needs because they cannot live alone. Each individual must be able to interact well with each other. However, not all individuals can establish a good relationship with another individual. To support the establishment of a good relationship are very important interpersonal intelligence possessed by everyone. Many people fail to realize how important the actual interpersonal intelligence.

The events of kindergarten development of interpersonal intelligence relates to all aspects of child development. At this stage of development of intrapersonal intelligence of preschool children more visible, children tend to express emotions freely and openly. Angry attitude often they exhibited as for the attention of the teacher, not sharing food with her friends or do not want to lend his belongings, by reason of his friend did that to him. This is where an kindergarten educators need to develop intrapersonal and interpersonal intelligences children early because kindergarten still do not know what to do and how to deal with such circumstances. Young children do not understand themselves and others.

Intrapersonal intelligence would be beneficial to the child alone in facing the problems of life, as many prominent figures were successful thanks to the high intrapersonal intelligence they have. When facing a thorny problem, he is also able to motivate himself to get up quickly and push yourself to achieve your goals or targets themselves. It is certain, these children will be spared from the conflict of interest, and to successfully deal with anticipated future full of thorny problems.

Reality on the ground intrapersonal and interpersonal intelligence is less noticed by the teacher in the school. As evidence of the schools only emphasizes the ability of logic (mathematics) and bahasa.Setiap increase in class, student achievement is measured only on the mathematical skills and thus bahasa.Dengan national education system that measures the level of intelligence of students who merely emphasizes the ability of logic and language should be revised.

Through play children can develop social skills such as developing relationships with other children, acting in accordance with the demands of society, adjusting to peers, can understand their own behavior, and understand that every action there is a consequence, through play children can increase the sensitivity of emotions by introducing a variety of feelings, introduce changes in feelings, to make a judgment as well as foster self-confidence. Through play children can express his negative attitude and positive impact on certain people, to release discomfort (upset). Because the game have an important role in the personal development of children (Ismail, 2006: 24).

Developing the ability to connect with people around (interpersonal) and the ability to understand oneself (intrapersonal) kindergarten can be pursued through the game designed by a kindergarten teacher. The process of playing designed by a kindergarten teacher to develop interpersonal and intrapersonal kindergarten can be done by learning through traditional games 
that develop support groups, establish rules of behavior, allow responsible, jointly resolve the conflict, doing social activities with peers, respecting differences of opinion between children with peers, foster friendly attitude and understand the social environment of cultural diversity, practice patience waiting for their turn to play and talk, and listen to the speech of others first. With traditional games is also a child can understand and predict the feelings, temperament, moods, intentions, desires of others, wishes yourself (understanding ourselves) who responded properly to direct the emotions themselves.

Through Boy Boyan game kindergarten teachers can build closeness, influence and relationships with other children in a fun, no pressure so that in addition to motor intelligence of children (intellectual, socio-emotional, language) intrapersonal and interpersonal intelligence that can grow well. According to Dockett and Fleer in Yuliani (2009: 144) considers playing activities as a means of socialization, is expected through play can give children the exploration opportunity, discover, express feelings, creativity, and learning fun. Besides that play activities can help children to know about himself, with whom he lives and the environment in which he lived.

Based on the above researchers are encouraged to investigate the learning program through Traditional Games to Develop Interpersonal intelligence and Intrapersonal of kindergarten students, with the title " The Effectiveness of Learning Programs Through Boy-Boyan Game to Depelove Interpersonal and Intrapersonal Intelligence of Kindergarten Students" (Study of Quasi-Experiment on Group B Kindergarten of PHBS and NEO Mahardika East Bandung Academic Year 2016/2017).

The research problem is formulated as follows: "How is the Effectiveness of Learning Program through Boy-boyan Games in developing interpersonal and intrapersonal intelligence of kindergarten students?"

The purpose of this research in general is to acquire knowledge and empirical evidence on the effectiveness of traditional games in the process of learning while playing as a tool in developing interpersonal and intrapersonal intelligence of kindergarten students. Specifically address all of the research questions that have been formulated by the researcher.

The benefits of research is to help strengthen and develop the treasures of the theory of practice types of traditional games that support the competence of kindergarten teachers appropriately and correctly in developing interpersonal and intrapersonal olds and can be used as a model to develop learning programs in kindergarten by practicing various traditional games olds early to develop interpersonal and intrapersonal kindergarten and help improve the system of learning in kindergarten in particular on the development of learning programs, syllabus, teaching methods and preparation of assessment instruments appropriate and tested the means, methods and steps correctly and actively involve kindergarten teacher.

\section{RESEARCH METHOD}

The research methods of this study is a quasi-experimental with quantitative approach. Using quasi-experimental method for this study is the everyday activities in the learning process is impossible to control all the variables that affect the free variable and tied tightly.

This study uses a quantitative research approach which is quasi experimental research design used (nonequivalent control groups design) in kindergarten of group B PHBS and Neo 
Mahardika West Bandung regency. According to Stouffer (1950) and Campbell (1957) in Dicky Hastjarjo (2008: 4) to formulate quasi experiment (quasi experiment) as an experiment that has treatment, impact measurement, units of the experiment, but do not use the assignment random to create benchmarking in order to conclude the changes caused treatment.

The comparison process depends on the comparison group was similar to many different things and not for their treatment. The task of researchers in interpreting the results of quasiexperimental design is to separate the effect of the treatment of the effects caused initial inequality among the units within each treatment group. The main concern only research on the effects of the treatment. To obtain this effect the separation, the researcher must declare a special threat to the validity of the conclusions that negated by random assignment and researchers must try to solve this problem. Quasi-experiment needs to be explicitly stated causal factors irrelevant "hidden" in ceteris paribus random assignment. A quantitative approach is used to assess the development of interpersonal and intrapersonal intelligence in kindergarten are already up and running. Meanwhile, a quantitative approach is also used to determine the validity of a rational program of traditional games. At the technical level to do the following steps: a descriptive analysis method, and quasi-experimental methods.

\section{RESULTS AND DISCUSSION}

Based on the real conditions in the field of kindergarten who are in PHBS and NEO Mahardika kindergarten in West Bandung which indicates that the level of interpersonal and intrapersonal intelligence in general in the category began to develop. The level of interpersonal development of kindergarten in the category began to grow about $60 \%$, the rest are in the category of developing according to expectations about $10 \%$ and $30 \%$ undeveloped category. While the level of intrapersonal development of kindergarten in the category began to grow $83.50 \%$ and the rest are in the category of underdeveloped $3.5 \%$ and $13 \%$ are in the category of developing according to expectations.

Based on research data in kindergarten of Neo Mahardika, found a variety of interpersonal intelligence profiles ranging from undeveloped, still developed, and undeveloped as expected. The number of children as many as twenty people on the research results pretest interpersonal intelligence achievement in kindergarten of NEO Mahardika three children are in the category of underdeveloped and seventeen children in the category began to developed. This suggested that for children who are in the category of underdeveloped allow better handling of teachers through stimulation and motivation during the learning through play and collaborate with parents in fostering and shaping behavior.

Based on the research results shown that the achievement of the development of interpersonal intelligence in PHBS and NEO Mahardika kindergarten students have no reached the good developement yet concerning the level of children development. This result is slightly different from the initial findings of the study on the preliminary study on the background issues that shows the intelligence of kindergarten students of Kartika generally tends to be in the category of underdeveloped and NEO Mahardika students began to develop.

Based on the findings of the profile the achievements of the development of interpersonal intelligence of children in kindergarten PHBS and NEO Mahardika of all the indicators of interpersonal intelligence is in the category started to develop a good indicator through observation based on the child's behavior can be seen in daily activities during lerning process by teachers and visible seen by researchers as children generally begin to estimate the feelings, 
moods, temperament and willingness friends and teachers. This is apparent when performing learning both in class and at play time can be fun friends and teachers as indicated by the behavior of children who tend to behave as follows:

Children begin to develop into friends with anyone good friends both male and female. This is apparent when performing game play mixed to form groups of both men and women. While indicators like helping a friend evident and when there are friends who have not been able to do a game other friends who helped provide examples of how to do that to his game. Further indicators such as interpersonal intelligence indicates excellence while leading in the group based on the findings of the kids were able to lead his friends. As at early time to go to class every child can lead the prayers of his friends when the teacher told the child to lead the prayers. While the ability to communicate effectively both verbal and non-verbal indicator there are still children who have not developed in the sense that there is still a silent despite telling her friends or teachers. But generally overall the kids are able to express desires, hopes, and feelings through conversation with their friends and teachers. Regarding indicators adaptable in a new place based on the findings in the field of children are still seen there are still timid, there which was used directly to join her friends without hesitation participate directly play. Although they have new friends that play in a new pleace, too.

Based on the findings of the study showed that the level of development of interpersonal and intrapersonal intelligence of both the kindergarten no one has reached the highest category that is growing very nice, either in PHBS or NEO Mahardika kindergarten students in West Bandung. This implies the need for attention to help improve interpersonal and intrapersonal intelligence is toward the higher and best quality of developement.

Children who have good intrapersonal intelligence developement will be more independent, to have a strong self-confidence, have clear objectives, have respect for themselves, dare to try, do not like to imitate and want to try to produce their own work.

The findings showed that learning in kindergarten so far generally do not provide for children to learn about themselves that involves the ability to understand and know themselves, what they want to do, how would they react to a situation, and understand the situation as what should be avoided. This is in accordance with the views expressed by Mulyani (2011) that teachers still use reprimands, penalties and habituation in improving attitudes and behavior of children that were not appropriate. While the kindergarten students according to Musfiroh (2011: 366) in development has had all the indicators of intrapersonal intelligence albeit in a form that is simple. But generally do not have intrapersonal intelligence above average.

Boy-boyan Game learning programs is one of approach being made to improve the learning activities in particular to develop interpersonal and intrapersonal intelligence for kindergarten students. The program was developed based on the objectives and specific conditions as a result of observations made by researchers after researchers conducted a preliminary study on PHBS and NEO Mahardika Kindergarten students Bandung in West Bandung Regency.

Test the effectiveness of learning programs through the game Boy Boyan to develop interpersonal intelligence kindergarten of PHBS and NEO Mahardika in West Bandung regency academic academic year 2016/2017 based on teacher assessment and observation researchers showed the same results. Based on the observations the researchers showed that the learning program through traditional games to enhance the development of more effective interpersonal improve interpersonal intelligence of children compared with conventional 
teaching methods aimed at there being a different increase in the average score normal that all the normal distribution of data because it has a value of $p>0.05$. This shows the variance of data pre-test and post-test data is interpersonal intelligence experimental and control groups homogeneous because it has a value of $p(\mathrm{sig})>0.05$. Based on the results of the independent $t-$ test and pre-test data is interpersonal intelligence experimental and control groups was not significant overall memilliki value of $\mathrm{p}>0.05$. This means that the pretest (before treatment) interpersonal intelligence of children there is no difference between the experimental and control groups.

While based on the data posttest interpersonal independent $t$-test, the data posttest experimental group and control interpersonal intelligence is significant because it has a value of $p>0.05$. This means that after treatment, the child interpersonal intelligence is no difference between the experimental and control groups. When viewed from an average of 83.65 over the experimental group than the control group at 70.50 meaningful interpersonal intelligence in the experimental group was better than the control group or in other words the treatment in the experimental group in the form of learning through effective Boy-Boyan game program in improve interpersonal intelligence of children. Based on the above data it can be concluded that the program of learning through play Boy-boyan effective for improving interpersonal intelligence of children in kindergarten PHBS Padalarang West Bandung regency.

Test the effectiveness of learning through games Boy Boyan program to improve interpersonal intelligence during the pretest tested based on the indicators it appears that the results of independent $t$ test interpersonal intelligence data is pre test experimental and control groups on each indicator is not significant because it has a value of $p>0.05$, It means when the pretest (before treatment) indicators interpersonal intelligence there were no differences between the experimental group and the control group. It means that at the time before treatment interpersonal intelligence of Kindergarten PHBS and NEO Mahardika no difference despite using different learning methods are different.

While based on the data posttest intrapersonal intelligence independent t-test, posttest data is experimental and control groups intrapersonal intelligence is significant because it has a value of $p>0.05$. This means that after treatment, the child intrapersonal intelligence is no difference between the experimental and control groups. When viewed from an average of 81.30 over the experimental group than the control group amounted to 70.60 meaningful interpersonal intelligence in the experimental group was better than the control group or in other words the treatment in the experimental group in the form of learning through traditional game program is effective in improving students intelligence.

\section{CONCLUSIONS AND SUGGESTION}

Based on the results of this study concluded that the program effective learning through traditional games to develop interpersonal and intrapersonal intelligence early childhood. These results indicate that it has acquired research instrument to detect and stimulate the development of interpersonal and intrapersonal children kindergarten are tested validity and reliability and tested constructs legibility has been reviewed by experts sehinnga can be used to stimulate and detect intelligence plural particularly interpersonal intelligence and intrapersonal. After the treatment, the child interpersonal intelligence is no difference between the experimental and control groups. When viewed from an average of 83.65 over the experimental group than the control group at 71.35 meaningful interpersonal intelligence in the experimental group was better than the control group or in other words the treatment in the experimental group in the 
form of learning through traditional game program is effective in improve interpersonal intelligence anak. Seen from the experimental group average of 81.30 is greater than the control group amounted to 70.60 meaningful interpersonal intelligence in the experimental group was better than the control group or in other words the treatment in the experimental group in the form of learning through the game program traditional effective in improving interpersonal intelligence of children.

As a sugestion for teachers, should position the child as a learning center in learning of overall activity, in particular to help develop interpersonal and intrapersonal intelligence of children, both in class and in the field of play. For kindergarten institutions should enhance the program according to the curriculum related to specific learning to develop learning activities both theoretical study and practical for children, so that children are able to develop of their intelligence whic is prominent / dominant in themselves.

\section{REFERENCES}

Armstrong, T. (2009). Multiple Intelligence in The Classroom. Alexandria, Virginia US: ASCD. Anak Cerdas Panduan membantu anakBelajar Dengan memanfaatkan multiple intelligence-nya. Alih bahasa: Rina Buntaran. Jakarta: Gramedia Pustaka Utama.

Campbel, Linda, Campbel, Bruce, dan Dickson. (2006) Metode Praktis Pembelajaran Berbasis Multiple Intelligences, Alih Bahasa Tim Intuisi. Jakarta: Intuisi Press.

Creswell, W.J. (2008). Research Design: Qualitative \& Quntitative Approach, Third Edotion. London: SAGE Publication.

Hastjarjo.Dicky (2008).Ringkasan buku Cook \& Campbell. (1979). Quasi-Experimentation: Design \& Analysis Issues for Field Settings. Houghton Mifflin Co.

Hurlock, E.B. (1980). Psikologi Perkembangan suatu pendekatan sepanjang rentang Kehidupan. Penerjemah: Istiwidayanti. Jakarta: Erlangga.

Ismail.Andang.(2006). Education Games Menjadi Cerdas dan Ceria dengan Permainan Edukatif. Yogyakarta: Pilar Media.

Jamaris, M (2004). Assesmen Pendidikan Anak Usia Dini, Seminar dan Lokakarya Nasional Pendidikan Anak Usia Dini di Jakarta.

Kwartolo.Yuli.(2005). Jurnal Pendidikan Penabur - No.04 / Th.IV / Juli 2005 Sumber intrapersonal ways of knowing (Adapted by Leslie Wesman from the work of Howard Gardner, Thomas Armstrong. Linda Campbell, and David Lazear.

Lwin, M. at.all. (2008). Cara Mengembangkan Berbagai Komponen Kecerdasan. Alih bahasa:Christiane Sujana. Jakarta: Indeks.

M. Husna. (2009) Permainan Tradisional Indonesia Untuk Ketangkasan, dan Keakraban Sesuai untuk Edukasi, Training, dan Outbond. Yogyakarta: ANDI. 
58 Komala. (2018). The Effectiveness Of Learning Programs Through Boy-Boyan Game to Develope Interpersonal and Intrapersonal Intelligence of Kindergarten Students. JEE, 1 (1), $51-58$.

Musfiroh, Tadkiroatun. (2011). Pengembangan Kecerdasan Majemuk. Jakarta: Universitas Terbuka. 